\title{
Post Cesarean Section Surgical Site Infection; Incidence and Risk Factors
}

\author{
Shaymaa Kadhim Jasim \\ Lecturer in Department of Obstetrics and Gynecology, College of Medicine, University of Baghdad
}

\begin{abstract}
The rate of births delivered by cesarean section (CS) has gone up substantially all over the world. Post-cesarean surgical site infection (SSI) is a common cause of maternal morbidity and mortality that results in prolonged period of hospitalization with increased cost and direct health implications, especially in low socioeconomic population, resource- restricted settings, and war- related conditions with internal forced movement. This study was aimed to find incidence of post cesarean section surgical site infection withthe accompanying risk factors.Pregnant ladies admitted to department of obstetrics and gynecology at Medical City Hospital in Baghdad who had undergone CSs were followed up prospectively from first of January 2017 till end of June 2017. Full medical evaluation was done to assess all clinical, laboratory, and sociodemographic characteristics ofboth; patients and controls. Statistical comparison was measured to appraise the important risk factors. A total of 3036 pregnant ladies were recruited, 191 patients had SSI with and an incidence rate of 6.3\%. The above- mentioned 191 patients constituted of 93 (48.7\%) internally moved patients due to the war, while they were 97 patients (25.4\%) out of 382 control-group. Obesity, diabetes mellitus, emergency CS, vertical incision, interrupted suturing, and rupture of membranes before CS, were significant risk factors of post CS SSI. Rate and several risk factors of post CS SSI were studied to increase the public attention, and to take full steps to decrease it prophylactically.
\end{abstract}

Keywords: Post cesarean surgical site infection, incidence, and risk factors

\section{Introduction}

Surgical site infection (SSI) is considered as one of the most common healthcare-associated infections, especially in low and middle-income countries. [1-3]

However; surgical site infection (SSI) after cesarean section is one of the major infections that can affect patients with a cesarean section (C-section) procedure. [4]

Caesarean section (CS) is among the most frequent surgical interventions in women all over the world. [5,6]

Despite recent surgical parameters and antibiotic prophylaxis, SSI is still standing significantly behind morbidity, mortality and healthcare-associated costs, especially if we know that CS increases the risk of postpartum infections by five to even twenty-fold compared to usual or vaginal delivery. [7-9]

Due to the worldwide ongoing rise in the incidence of cesarean deliveries, the number of women with postpartum infection is expected to increase. The SSI following CS causes physical, psychological and financial burden to the lady, her family and community. [10-12]

Difficulties to the mother and her family are exaggerated when SSI develops, especially in today's climate of early hospital discharge, which leaves women to stay at home, sometimes with little practical and/ or emotional support. [13]

Obstetrical surgery involves some degree of contamination, and is classified as" clean- contaminated" cases, even when the patient has no preoperative signs and symptoms of active infection. So; pregnant women are at risk of infection during delivery, which may be enhanced by the relative immunocompromised state of pregnancy. [14]
Risk factors contributing to an increase in SSI post CS are widely variable such as gross contamination of the operative site, prolonged and premature rupture of membranes, prolonged operative time, obstructed labor, obesity, chorioamnionitis, emergency operation and decreased immune status, which are especially common in poor countries where women may be malnourished and chronically anemic. [15-18]

\section{Aim}

To find out the incidence and associated risk factors of SSI after CS which may have an impact on increasing alertness among obstetricians aiming to prevent such a problem.

\section{Methods}

This prospective study was conducted in the department of obstetrics and gynecology, Medical City Hospital, Baghdad, Iraq, from the first of January 2017 till end of June of the same year.

A total number of 3036 women who had undergone CS as a mode of delivery were enrolled, with ladies who had exploratory laparotomy after lower segment CS were excluded.

Medical history and examination were done for all patients by the attending obstetrician, with wound examination for the development of SSI when women got back for stich removal around ten days post-operatively or at any other visit during puerperium.

For each one confirmed case of SSI, two randomly selected cases with no SSI (from the same total sample of patients within study period) were considered as a control to compare and identify any associated risk factor with SSI. Also; for each patient, either in diseased or control group; there had been some specific information collected such as: age, parity, address (to document if woman was native or

Volume 6 Issue 7, July 2017 www.ijsr.net 


\section{International Journal of Science and Research (IJSR) \\ ISSN (Online): 2319-7064 \\ Index Copernicus Value (2015): 78.96 | Impact Factor (2015): 6.391}

internally moved), CS type (emergency or elective), academic level (according to literacy), history of smoking, occupation, and level of hematocrit (as anemia was considered when hematocrit (PCV) was less than $30 \%$ immediately before surgery. [19]

Fasting blood sugar measurements were documented at time of CS, and diabetes mellitus was diagnosed when it exceeded $105 \mathrm{mg} / \mathrm{dl}$. [20]

Body mass index (BMI) was calculated for all patients depending on their height and weight. We divided BMI readings into two categories; either $<30$ (non-obese) or $\geq 30$ (obese). [1,21,22]

Regarding SSI, all types were involved in this study which included: [23]

Superficial SSI: infection involves just skin or underlying subcutaneous tissue that was managed in a conservative way by daily dressing and appropriate antibiotics.

Deep incisional SSI: infection involves deep tissue (like fascial and muscle layers) or presence of wound dehiscence which needed secondary suturing.

Organ/ space SSI: infection involves any part of the anatomy (e.g. organs or spaces), apart from the incision, which was manipulated during an operation that required exploration and suturing. Statistical analysis was accomplished using Statistical Package for the Social Sciences (SPSS), version 24, with $\mathrm{P}$ value of $<0.05$ was considered as statistically significant.

\section{Results}

Out of 3036 women involved, 191(6.3\%) of them had SSI, which represents the incidence rate of SSI post CS in our setting. Ladies whom $<20$ years old were 392 (12.9\%), while they constituted 1582 patients $(52.1 \%)$ when they aged 20 - 30 years old, and 917 (30.2\%) women were within an age range of $30-40$ years old, and finally when they were $>40$ years old, $145(4.8 \%)$ women were found in our sample.

Table (1) shows general characteristics of case- group (patients with SSI) and control- group (with no SSI), where we had no statistically significant differences for all variables except for obesity (body mass index $\geq 30$ ). These risk factors (variables) included age of the pregnant mothers, parity, smoking behavior, education status (literate or nonliterate), and main work or duty that these ladies whom entered into this study had for living or daily practice.

Emergency CS, membrane rupture before delivery, and sort of abdominal skin incision and / or suture, played an important statistically significant role being risk factors to develop SSI, as detailed in table (2).

Anemia and diabetes were more common with SSI patients, but only diabetes readings reached the significant level ( $\mathrm{P}$ value $<0.05$ ), as mentioned in table (3).
Table 1: General clinical, social, and demographic features for cases and controls

\begin{tabular}{|c|c|c|c|}
\hline Variables & Case $(n=191)$ & $\begin{array}{c}\text { Control } \\
(n=382)\end{array}$ & P value \\
\hline Age, mean \pm SD & $25.3 \pm 7.6$ & $26.2 \pm 7.4$ & 0.0783 \\
\hline Parity, mean \pm SD & $4.8 \pm 0.6$ & $5.1 \pm 0.8$ & 0.8795 \\
\hline $\begin{array}{c}\text { BMI (kg/m2), } \\
\text { mean } \pm \text { SD: } \\
<30 \text { (non-obese) } \\
\geq 30 \text { (obese) }\end{array}$ & $28.4 \pm 5.9$ & $28.2 \pm 7.4$ & 0.004 \\
\hline $\begin{array}{c}\text { Smoking status, } \mathrm{n} \\
\text { (\%) }\end{array}$ & $35.6 \pm 8.3$ & $30.4 \pm 6.5$ & \\
$\begin{array}{c}\text { Smoker } \\
\text { Non-smoker }\end{array}$ & $181(9.2 \%)$ & $23(6.0 \%)$ & 0.6592 \\
\hline $\begin{array}{c}\text { Academic level, } \mathrm{n} \\
(\%)\end{array}$ & $182(95.3 \%)$ & $359(94.0 \%)$ & \\
Literate & $9(4.7 \%)$ & $16(4.2 \%)$ & 0.9847 \\
Illiterate & & & \\
\hline $\begin{array}{c}\text { Occupation: } \\
\text { Housewife } \\
\text { Employed }\end{array}$ & $152(79.6 \%)$ & $306(80.1 \%)$ & 0.8936 \\
\hline \multicolumn{2}{|c|}{$56(20.4 \%)$} & $76(19.9 \%)$ & \\
\hline
\end{tabular}

Table 2: Operation- related risk factors for cases and

\begin{tabular}{|c|c|c|c|}
\hline Risk factor & $\begin{array}{c}\text { Case } \\
(n=191)\end{array}$ & $\begin{array}{c}\text { Control } \\
(n=382)\end{array}$ & P value \\
\hline $\begin{array}{c}\text { Type of CS, n (\%) } \\
\text { Emergency } \\
\text { Elective }\end{array}$ & $\begin{array}{c}170(89.0 \%) \\
21(11.0 \%)\end{array}$ & $\begin{array}{c}197(51.6 \%) \\
185(48.4 \%)\end{array}$ & 0.0001 \\
\hline $\begin{array}{c}\text { Types of incision, n (\%): } \\
\text { Vertical }\end{array}$ & $74(38.7 \%)$ & $60(15.7 \%)$ & 0.0001 \\
Horizontal & $117(61.3 \%)$ & $322(84.3 \%)$ & \\
\hline $\begin{array}{c}\text { Type of skin suturing: } \\
\text { Interrupted }\end{array}$ & $132(69.1 \%)$ & $91(23.8 \%)$ & 0.0001 \\
Subcuticular & $59(30.9 \%)$ & $291(76.2 \%)$ & \\
\hline $\begin{array}{c}\text { Rupture of membranes } \\
\text { before CS: } \\
\text { Yes }\end{array}$ & $119(62.3 \%)$ & $117(30.6 \%)$ & 0.0001 \\
No & $72(37.7 \%)$ & $265(69.4 \%)$ & \\
\hline
\end{tabular}

Table 3: Laboratory parameters for cases and controls

\begin{tabular}{|c|c|c|c|}
\hline $\begin{array}{c}\text { Parameter } \\
\text { (disease) }\end{array}$ & Case $(n=191)$ & Control $(n=382)$ & P value \\
\hline Diabetes mellitus & $37(19.4 \%)$ & $16(8.4 \%)$ & 0.0011 \\
\hline Anemia & $74(38.7 \%)$ & $127(33.2 \%)$ & 0.6483 \\
\hline
\end{tabular}

\section{Discussion}

Cesarean section (CS) is one of the commonest and most famous surgeries in obstetrics. Surgical site infections (SSI) rise maternal morbidity, elongate hospital admission, and have a direct effect on healthcare cost. [10]

Usually most data and articles come from modern world, with high quality medical services and an effective health system, but their findings, conclusions, and recommendations would not always fit other parts of the world with restricted resources and limited facilities.

Herein this prospective study, in addition to the above point, another important aspect could be added regarding patients whom internally moved due to a war waged in the country, after terrorism caused by appearance of what was called [Islamic State in Iraq and Syria (ISIS)] in some regions of Iraq.

\section{Volume 6 Issue 7, July 2017 www.ijsr.net}




\section{International Journal of Science and Research (IJSR) \\ ISSN (Online): 2319-7064}

Index Copernicus Value (2015): 78.96 | Impact Factor (2015): 6.391

According to our knowledge, no data were published up to date dealing with such difficult circumstances.

The current study was performed in a university-affiliated tertiary obstetrics and gynecology center which received patients` referrals from different parts of the state. Many of pregnant ladies visiting this center were part of families forced to leave their local regions and moved to safer areas within the country. Precisely, 93 patients $(48.7 \%)$ out of 191 patients with SSI after CS, and 97 patients $(25.4 \%)$ out of 382 control- patients.

Reporters at different parts of the world gave a wide range of readings for rates of SSI after CS, from $0.3 \%-48 \%$. $[1,24,25]$

The rate of SSI related to CS in our data was $6.3 \%$, which is considered low in comparison to other parts of the globe, like in Norway (8.3\%) [26], UK (9.6\%) [27], and (17\%) in Australia [28]. Going to Africa; 9.1\% was in Nigeria [19], $11.4 \%$ in Ethiopia [29], and an extremely high rate (48\%) in Tanzania [1]. While in India; it was $7.4 \%$ which was slightly higher than this study. [24]

Lower rates were found in United States (5\%), and New Zealand (5\%) [30], while in Rwanda it was slightly lower $(4.9 \%)$. [11]

Amazingly; The lowest rates were noticed in the Middle East, as $(0.3 \%)$ in Turkey [31], $(2.66 \%)$ in Oman [32], and an old data from a remote town in Iraq (2.9\%). [33]

Most of collected patients with SSI were detected usually after returning back to hospital for stich removal as a scheduled visit in harmony with hospital policy, so that; this rate may be lower than the real, as not all patients came back to the same hospital when they had SSI, especially if we add the difficult situations of internally moved patients when they could not reach the hospital easily, in spite of limited availability of medical care at their camps or even private interim houses, which in turn, may increase the risk of SSI within this group of patients.

Lower SSI rates in the Middle East may be due to the approach of detection method (during hospital stay or after discharge), accuracy of registration system, and/ or antibiotics abuse, when patients usually take antibiotics even without prescription before CS incision.

However; our incidence of SSI was even higher than other neighbors. About half of SSI cases $(48.7 \%)$ were internally moved people with all their background deficient capabilities to take prophylactic measures regularly, or seek medical help at the right time when SSI developed.

Cesarean sections performed by trainees or insufficiently experienced obstetricians (usually available at a university hospital), may be blamed for a more delay in operation time and add another justification point about our high incidence of SSI. [10,34]

Variable risk factors of post cesarean section surgical site infection were investigated within this study, revealing the following significant risk factors; Obesity, emergency CS, vertical incision, interrupted sutures, rupture of membranes before CS, and diabetes mellitus.

Obesity was a well-known cause for many workers and may be related to hypo-vascular thick subcutaneous tissue which results in lower immunity, larger and / or longer than usual CS incision with wider wound, and less availability of penetrated antibiotics into adipose tissues. [22,35]

Emergency CS has been linked to SSI through more frequent vaginal examinations with greater opportunity for membranes to rupture before delivery, highly urgent operation, less concerns about sterility, and absence of prophylactic antibiotics on time. [36-38]

Some authors found Type of CS (either emergency or elective) was not a significant risk factor of SSI. [19,25]

A vertical incision of CS was mentioned by many papers to increase the risk of SSI and may lead to formation of a hematoma due to less vascular tissues, while a transverse incision was associated with less wound dehiscence. [39-41] Suturing techniques played an important role in SSI development after CS, interrupted suturing was a good predictor of SSI, when compared to a subcuticular technique which had lower infection events. [23,42]

The rupture of membranes before CS was attributed to SSI risk factors. An infected amniotic fluid may transfer pathogens into $\mathrm{CS}$ incisions with chorioamnionitis could be a final result. [40,43]

There was a strong relation between post CS SSI and diabetic mothers. The idea of improper white blood cells function, and the metabolic abnormalities of diabetes lead to impaired migration of neutrophils and macrophages to the infected wound, in line with chemotaxis reduction, may explain the above link. [23,24,27]

Some reporters showed no real relation with diabetes in spite of some increase in incidence of SSI after CS. [22,45]

Anemia at time of CS in these series did not significantly affect SSI rates, in favor of other publishes. [24]

Other researchers documented anemia after CS as a significant risk factor due to intraoperative blood loss, which was not measured by our data due to lack of information. $[19,35]$

Non-significant risk factors found in this data were supported by others, when there was a trend towards a younger age group, and less parity or even nulliparity. $[10,19,35,46]$

This study has some strong aspects; such as its large sample size of patients, it may be the first to involve internally moved patients with low potentials of medical and social facilities, and the setting where this research had been performed, which was considered the largest and best obstetrics center in the whole country (in spite of the above mentioned limited potentials).

\section{Volume 6 Issue 7, July 2017 www.ijsr.net}




\section{International Journal of Science and Research (IJSR) \\ ISSN (Online): 2319-7064}

Index Copernicus Value (2015): 78.96 | Impact Factor (2015): 6.391

We could not follow up all patients completely due to lack of an effective follow up screening method for SSI after CS, and difficult or abnormal circumstances that some of our patients might had (forceful internal movement). Other potential risk factors such as amount of blood loss, number of vaginal examinations before CS, duration of cesarean operation, and an elapsed time before surgery since rupture of membranes, were not measured during this study because of unavailability of sufficient resources within a medical facility. All these could be considered as weak aspects of this study.

\section{Conclusion}

Standing on the most important points to identify risk factors of SSI after CS, with its incidence rate, would lead obstetricians to pay more attention during daily practice, and paving a roadmap to prevent or decrease the rate of these infections, especially in low socioeconomic societies where it is hard to identify post CS SSI and even to treat it.

\section{References}

[1] Nguhuni B, De Nardo P, Gentilotti E, Chaula Z, Damian C, Mencarini P, Nicastri E, Fulment A, Piscini A, Vairo F, Aiken AM. Reliability and validity of using telephone calls for post-discharge surveillance of surgical site infection following caesarean section at a tertiary hospital in Tanzania. Antimicrobial Resistance \& Infection Control. 2017 May 8;6(1):43.

[2] Bagnall NM, Vig S, Trivedi P. Surgical-site infection. Surgery (Oxford). 2009 Oct 31;27(10):426-30.

[3] Rothe C, Schlaich C, Thompson S. Healthcareassociated infections in sub-Saharan Africa. J Hosp Infect. 2013;85(4):257-67.

[4] Halwani MA, Turnbull AE, Harris M, Witter F, Perl TM. Postdischarge surveillance for infection following cesarean section: a prospective cohort study comparing methodologies. American journal of infection control. 2016 Apr 1;44(4):455-7.

[5] Mpogoro FJ, Mshana SE, Mirambo MM, Kidenya BR, Gumodoka B, Imirzalioglu C. Incidence and predictors of surgical site infections following caesarean sections at Bugando medical Centre, Mwanza, Tanzania. Antimicrob Resist Infect Control. 2014; 3:25.

[6] Hadiati DR, Hakimi M, Nurdiati DS. Skin preparation for preventing infection following caesarean section. Cochrane Database of Systematic Reviews. 2012;(9). Art. No: CD007462.

[7] Conroy K, Koenig AF, Yu Y, Courtney A, Lee HJ, Norwitz ER. Delivery: 10 strategies to reduce risk. Rev Obstet Gynecol. 2012;5(2):69-77.

[8] Lyimo FM, Massinde AN, Kidenya BR, Konje E, Mshana SE. Efficacy of single dose of gentamicin in combination with metronidazole versus multiple doses for prevention of post-caesarean infection: study protocol for a randomized controlled trial. Trials. 2012; 13:89.

[9] Brown J, Thompson M, Sinnya S, Jeffery A, de Costa C, Woods C, et al. Pre-incision antibiotic prophylaxis reduces the incidence of post-caesarean surgical site infection. J Hosp Infect. 2013;83(1):68-70.

[10] Olsen MA, Butler AM, Willers DM, Devkota P, Gross GA and Fraser VJ. Risk factors for surgical site infection after low transverse cesarean section. Infect Control HospEpidemiol2008; 9:477-84.

[11] Bizimana JK, Ndoli J, Bayingana C, Baluhe I, Gilson GJ, Habimana E. Prevalence and Risk Factors for Post Cesarean Delivery Surgical Site Infection in a Teaching Hospital Setting in Rural Rwanda: A Prospective Cross Sectional Study. Int. J. Curr. Microbiol. App. Sci. 2016;5(6):631-41.

[12] Bahufite A, Bahufite A, Ndagijimana A, Ndagijimana A, Adomako E, Adomako E, Zerihun A, Zerihun A, Simba CA, Simba CA, Ntakirutimana C. Implementing wound dressing protocol to reduce post cesarean section surgical site infections in Mibilizi District Hospital, Rwanda. On the Horizon. 2016 Sep 12;24(4):369-76.

[13] Gould D. Caesarean sec on, surgical site infection and wound management. Nursing Standard 2006 Nov;21(32):57-66.

[14] CDC/NHSN Surveillance definition of healthcareassociated infection and criteria for specific types of infection in the acute care setting. 2013. Centers for Disease Control and Prevention.http://www.cdc.gov/nhsn/PDFs/pscManual/ 17pscNosInfDef_current.pdf

[15] Walsh C, Scaife C, Hopf H. Prevention and management of surgical site infections in morbidly obese women. Obstet Gynecol.2009;113(2, Part 1):411-415.

[16] Opøien HK, Valbø A, Grinde-Andersen A, Walberg M. Post-cesarean surgical site infections according to CDC standards: rates and risk factors. A prospective cohort study. ActaObstetGynecol Scand. 2007;86(9):1097-102.

[17] Taylor SE, Gosman GG, Kelley JL. An Assessment of Risk Factors for Surgical Site Infection and Superficial Wound Separation in Gynecologic Oncology Patients. of. $2017 ; 5: 2$.

[18] Raka, L., Zounman, D. 2006. Prevalence of nosocomial infections in high risk units in the University clinical center of Kosovo. Infect. Control and Hospital Epidemiol., 27(4): 421-423.

[19]Jido TA, Garba ID. Surgical-site infection following cesarean section in Kano, Nigeria. Annals of medical and health sciences research. 2012;2(1):33-6.

[20] Martin ET, Kaye KS, Knott C, Nguyen H, Santarossa M, Evans R, Bertran E, Jaber L. Diabetes and risk of surgical site infection: a systematic review and metaanalysis. infection control \& hospital epidemiology. 2016 Jan;37(1):88-99.

[21] Pursey K, Burrows TL, Stanwell P, Collins CE. How accurate is web-based self-reported height, weight, and body mass index in young adults? Journal of medical Internet research. 2014 Jan;16(1).

[22] Leth RA, Uldbjerg N, Nørgaard M, Møller JK, Thomsen RW. Obesity, diabetes, and the risk of infections diagnosed in hospital and post-discharge infections after cesarean section: a prospective cohort study. Actaobstetricia et gynecologicaScandinavica. 2011 May 1;90(5):501-9.

[23] Shrestha S, Shrestha R, Shrestha B, Dongol A. Incidence and risk factors of surgical site infection 


\section{International Journal of Science and Research (IJSR) \\ ISSN (Online): 2319-7064}

Index Copernicus Value (2015): 78.96 | Impact Factor (2015): 6.391

following cesarean section at Dhulikhel Hospital. Kathmandu University Medical Journal. 2015 Oct 13;12(2):113-6.

[24] Afzal A, Nawaz S. Risk Factors Associated with Wound Infection Following Caesarean Section-A Hospital Based Study, 2016.

[25] Mitt P, Lang K, Peri A, Maimets M. Surgical-site infections following cesarean section in an Estonian university hospital: postdischarge surveillance and analysis of risk factors. Infection Control \& Hospital Epidemiology. 2005 May;26(5):449-54.

[26] Eriksen HM, Sæther AR, Løwer HL, Vangen S, Hjetland R, Lundmark H, Aavitsland P. Infections after caesarean sections. Journal of Norwegian Medical Associa on. Tidsskr Nor Legeforen 2009; 129:618-22.

[27] Wloch C, Wilson J, Lamagni T, Harrington P, Chalett A, Sheridan E. Risk factors for surgical site infection following caesarean section in England: Result from a multicentre cohort study; BJOG An International Journal of Obstetrics and Gynaecology. 2012;119(11):1324-1333.

[28] Noy D, Creedy D. Postdischarge surveillance of surgical site infections: a multi-method approach to data collection. Am J Infect Control 2002; 30:417-424.

[29] Amenu D, Belachew T and Araya F. Surgical site infection rate and risk factors among obstetric cases of Jimma University specialized hospital, Southwest Ethiopia. Ethiop Journal of Health Science 2011 July;21(2).

[30] Infection Control Services. Surgical Site Infection Surveillance in Obstetrics. Waikato Hospital; 2007.

[31] Yalcin AN, Bakir M, Bakici Z, Dokmetas I, Sabir N. Postoperative wound infections. J Hosp Infect 1995; 29:305-309.

[32] Dhar H, Busaidi AI, Rathi B, Nimre A E, Sachdeva V and Hamdi I. A Study of Post-Caesarean Sec on Wound Infections in a Regional Referral Hospital, Oman. Sultan Qaboos University Med J 2014 May; (14)2: e211-21.

[33] M. Alsabbak, Rafah Sadiq. Wound infection following cesarean section, Bas J Surg, 2003.

[34] Killian CA, Graffunder EM, Vinciguerra TJ, Venezia RA. Risk factors for surgical- site infections following cesarean section. Infect Control HospEpidemiol 2001; 22:613-7.

[35] Ghuman M, Rohlandt D, Joshy G, Lawrenson R. Postcaesarean section surgical site infection: rate and risk factors. The New Zealand Medical Journal (Online). 2011 Jul 29;124(1339).

[36] De D, saxena S, Mehata G, Yadav R, and Du a R. Risk factor analysis and microbial etiology of surgical site infections following lower segment caesarean sec on. International Journal of Antibiotics 2013; Volume 2013, Article ID 283025, 6 pages

[37] Cocoran S, Jackson V, Smith C S, Loughrey J. Kenna MC, Cafferkey M. Surgical site infection after cesarean section: Implementing 3 changes to improve the quality of patient care. Dublin, Ireland. American Journal of Infection Control 2013; 41:1258-63

[38] Nielsen T, Hokegard K. Cesarean Section and Intraoperative Surgical Complications. Acta Obstet Gynecol Scand.1984;63(2):103-108.
[39] Killian CA, Graffunder EM, Vinciguerra TJ, Venezia RA. Risk factors for surgical-site infections following cesarean sec on. Infect Control HospEpidemiol2001; 22:613-17.

[40] Martens MG, Kolrud BL, Faro S, Maccato M, Hammill H. Development of wound infection or separation after cesarean delivery: Prospective evaluation of 2431 cases. Journal for Reproductive Medicine for Obstetrician and Gynaecologist. 1995;40(3):171-5.

[41] Thawal A Y, and Waghmare M. A Comparative Study Between Midline Vertical and Pfannestiel incision in lower Segment Caesarean Sec on With Reference to Wound Complications. Indian Journal of applied research 2014;4(10).

[42] Caesarean section surgical site infection surveillance. Wexford general hospital. 2009 to 2011 comparative report.

[43] Mpogoro et al. Incidence and predictors of surgical site infections following caesarean sections at Bugando Medical Centre, Mwanza, Tanzania. Antimicrobial Resistance and Infection Control 2014; 3:25.

[44] Delamaire M, Maugendre D, Moreno M, et al. Impaired leucocyte functions in diabetic patients. Diabet Med. 1997;14(1): 29-34.

[45] Schneid-Kofman N, Sheiner E, Levy A, Holcberg G. Risk factors for wound infection following cesarean deliveries. Int J Gynaecol Obstet. 2005; 90:10-15.

[46]Chang PL, Newton ER. Predictors of antibiotic prophylactic failure in post-cesarean endometritis. ObstetGynecol 1992; 80:117-22. 